\title{
Low-dose IGF-I has no selective advantage over insulin in regulating glucose metabolism in hyperglycemic depancreatized dogs
}

\author{
S J Fisher ${ }^{1}$, Z Q Shi ${ }^{1,2}$, H L Lickley ${ }^{1,2}$, S Efendic ${ }^{4}$, M Vranic ${ }^{1,3}$ \\ and $\mathbf{A}$ Giacca $^{1,3}$ \\ ${ }^{1}$ Department of Physiology, University of Toronto, Toronto, Ontario, Canada \\ ${ }^{2}$ Department of Surgery, University of Toronto, Toronto, Ontario, Canada \\ ${ }^{3}$ Department of Medicine, University of Toronto, Toronto, Ontario, Canada \\ ${ }^{4}$ Department of Endocrinology, Karolinska Hospital, Stockholm, Sweden \\ (Requests for offprints should be addressed to A Giacca, Department of Physiology, University of Toronto, Room 3352, Medical Sciences Building, \\ 1 King's College Circle, Toronto, Ontario M5S 1A8, Canada; Email: adria.giacca@utoronto.ca)
}

\begin{abstract}
At supraphysiological levels, IGF-I bypasses some forms of insulin resistance and has been proposed as a therapeutic agent in the treatment of diabetes. Unfortunately, side effects of high-dose IGF-I $(100-250 \mu \mathrm{g} / \mathrm{kg})$ have precluded its clinical use. Low-dose IGF-I $(40-80 \mu \mathrm{g} / \mathrm{kg})$, however, shows minimal side effects but has not been systematically evaluated. In our previous study under conditions of declining glucose, low-dose IGF-I infusion was more effective in stimulating glucose utilization, but less effective in suppressing glucose production and lipolysis than low-dose insulin. However, under conditions of hyperglycemia, we could not observe any differential effects between high-dose infusions of IGF-I and insulin. To determine whether the differential effects of IGF-I and insulin are dose-related or related to the prevailing glucose level, $3 \mathrm{~h}$ glucose clamps were performed in the same animal model as in the previous studies, i.e. the moderately hyperglycemic $(175 \mathrm{mg} / \mathrm{dl})$ insulin-infused depancreatized dog, with additional infusions of low-dose IGF-I $(67 \cdot 8 \mu \mathrm{g} / \mathrm{kg}$, i.e. $29 \cdot 1 \mu \mathrm{g} / \mathrm{kg}$ bolus plus $0 \cdot 215 \mu \mathrm{g} / \mathrm{kg}$ per min infusion; $n=5$ ) or insulin
\end{abstract}

$49.5 \mathrm{mU} / \mathrm{kg}(9 \mathrm{mU} / \mathrm{kg}$ bolus plus $0.45 \mathrm{mU} / \mathrm{kg}$ per min; $n=7$ ). As in the previous study under conditions of declining glucose, low-dose IGF-I had significant metabolic effects in vivo, in our model of complete absence of endogenous insulin secretion. Glucose production was similarly suppressed with both IGF-I and insulin, by $54 \pm 3$ and $56 \pm 2 \%$ S.E. $(P=\mathrm{NS})$ respectively. Glucose utilization was stimulated to the same extent (IGF-I $5 \cdot 2 \pm 0 \cdot 2$, insulin $5 \cdot 5 \pm 0 \cdot 3 \mathrm{mg} / \mathrm{kg}$ per min, $P=\mathrm{NS}$ ). Glucagon, free fatty acid, glycerol, alanine and betahydroxybutyrate, were suppressed, while lactate and pyruvate levels were raised, similarly with IGF-I and insulin. We conclude that: (i) differential effects of IGF-I and insulin may be masked under hyperglycemic conditions, independent of the hormone dose; (ii) low-dose IGF-I has no selective advantage over additional insulin in suppressing glucose production and lipolysis, nor in stimulating glucose utilization during hyperglycemia and subbasal insulin infusion when insulin secretion is absent, as in type 1 diabetes mellitus.

Journal of Endocrinology (2001) 168, 49-58

\section{Introduction}

Insulin-like growth factor-I (IGF-I) is structurally similar to insulin and at pharmacological doses can mimic many of the effects of insulin on carbohydrate, lipid and protein metabolism. The stimulatory effect of IGF-I on glucose metabolism had prompted interest in its possible therapeutic use as an adjuvant treatment of diabetes. Unfortunately, high doses of IGF-I in the range of $100-250 \mu \mathrm{g} / \mathrm{kg}$ and up to $500 \mu \mathrm{g} / \mathrm{kg}$ administered either i.v. or s.c. have been associated with adverse side effects (Schalch et al. 1993, Jabri et al. 1994, Usala et al. 1994, Moses et al. 1996). Minor side effects include weight gain, facial and hand edema and temporomandibular tenderness; more serious side effects include symptomatic hypoglycemia, Bell's palsy, acromegaloid features, increased intracranial pressure, gynecomastia and avascular necrosis of the femur (reviewed in Bondy et al. 1994 and Malozowski \& Stadel 1994). There has also been concern regarding the possible contribution of IGF-I to potentiate diabetic complications (Meyer-Schwickerath et al. 1993, Janssen et al. 1997).

Recent reports, however, suggest that lower IGF-I doses in the range of $40-80 \mu \mathrm{g} / \mathrm{kg}$ are better tolerated and show minimal or no adverse side effects in diabetic subjects (Bach et al. 1994, RINDS 1996a, b. Acerini et al. 1997, Carroll et al. 1997, Quattrin et al. 1997). Clinical 
trials have shown that low-dose s.c. IGF-I (in the range $40-80 \mu \mathrm{g} / \mathrm{kg}$ ) can decrease insulin requirements, lower glycated hemoglobin and fasting glycemia, and improve insulin sensitivity in both type 1 (Acerini et al. 1997, Carroll et al. 1997, Quattrin et al. 1997) and type 2 diabetic subjects (Cusi \& DeFronzo 1995, RINDS 1996a, b). Unfortunately, the acute metabolic responses to these low doses of IGF-I have been less well characterized. Many of the differential effects of IGF-I vs insulin in acutely stimulating glucose metabolism observed at higher doses (above $100 \mu \mathrm{g} / \mathrm{kg}$ ) are not observed at lower doses (Laager et al. 1993, Boulware et al. 1994). Studies comparing metabolic responses to high- and low-dose IGF-I infusion have found that glucose kinetics may not respond in a dose-dependent fashion (Shojaee-Moradie et al. 1995), which may be related to the effects of circulating IGF-binding proteins or variable suppression of endogenous insulin and/or glucagon. Few studies have assessed the acute metabolic responses to low-dose IGF-I administration in diabetic subjects. Cheetham et al. (1993) noted that a single IGF-I dose of $40 \mu \mathrm{g} / \mathrm{kg}$ resulted in a decreased insulin requirement to maintain euglycemia in type 1 diabetic adolescents. Acerini et al. (1997) noted that in response to a single $40 \mu \mathrm{g} / \mathrm{kg}$ injection of IGF-I in type 1 diabetic subjects there were decreased insulin requirements and an increased hepatic insulin sensitivity. To date, a comparison between the acute metabolic responses to low-dose IGF-I and insulin has not been reported in hyperglycemic diabetic subjects. Given the renewed clinical interest in low-dose IGF-I administration with its favorable safety profile, it is important to assess under diabetic conditions whether lowdose IGF-I has any selective advantage over insulin administration (possibly by binding to the IGF-I receptor).

We have previously reported that low-dose IGF-I $(67 \cdot 8 \mu \mathrm{g} / \mathrm{kg})$ increased glucose utilization and lactate more, and suppressed glucose production (GP) and lipolysis less, than an equipotent dose of insulin under conditions of a glucose decline (Giacca et al. 1990). Equipotency on whole body glucose metabolism was judged based on the hormone doses required to induce the same lowering of plasma glucose (this required a greater stimulation of glucose utilization but less inhibition of GP with IGF-I than insulin). Since that study suggested that the IGF-I/insulin potency ratio is higher in muscle than liver or adipose tissue, we proposed that some insulin-like effects of IGF-I in vivo could be mediated not only through the insulin receptor, but also through the IGF-I receptor. We then observed that these differential effects of IGF-I and insulin on glucoregulation were masked when higher doses of IGF-I ( $>100 \mu \mathrm{g} / \mathrm{kg}$ ) and insulin (also equipotent based on similar requirements for exogenous glucose infusion during the glucose clamp) were administered under conditions of maintained hyperglycemia (Giacca et al. 1994). Thus, it was unclear whether the failure to reproduce the differential effects of IGF-I and insulin was dose-related (high-IGF-I doses may cross-react to a greater extent with the insulin receptor than low-IGF-I doses) or dependent on the maintenance of hyperglycemia.

The aim of the present study was to compare the acute metabolic responses of low-dose IGF-I to low-dose insulin administration under conditions of hyperglycemia. The total IGF-I dose was $67.8 \mu \mathrm{g} / \mathrm{kg}$ administered over $3 \mathrm{~h}(29 \cdot 1 \mu \mathrm{g} / \mathrm{kg}$ bolus $+0 \cdot 215 \mu \mathrm{g} / \mathrm{kg}$ per min infusion). As in our previous studies (Giacca et al. 1990, 1994), depancreatized dogs were used as the experimental model, which allowed assessment of IGF-I action on extrapancreatic tissues independent of the insulin suppression effect of IGF-I. In the basal period, steady-state moderate hyperglycemia was maintained by a subbasal intraportal insulin infusion; then an additional infusion of low-dose IGF-I or insulin was administered peripherally. Thus, the experimental design allowed us to compare the effects of IGF-I+insulin to those of insulin alone. Plasma glucose was maintained at the initial hyperglycemic levels with the glucose clamp protocol.

\section{Materials and Methods}

\section{Animals}

Male mongrel dogs weighing 17-24 kg underwent total pancreatectomy and vessel cannulation under general anesthesia and assisted ventilation, induced with $25 \mathrm{mg} / \mathrm{kg}$ thiamylal sodium and maintained with $0 \cdot 5-1 \%$ halothane in carrier gas containing nitrous oxide $(2.51 / \mathrm{min})$ and oxygen $(3.51 / \mathrm{min})$. During surgery, silastic cannulae (Dow Corning Corp., Midland, MI, USA) were inserted, (i) into the carotid arch via the carotid artery (0.04 inch internal diameter (i.d.)) for sampling, (ii) into the superior vena cava via the jugular vein (three 0.03 inch i.d. cannulae) for peripheral infusions of tracer and insulin or IGF-I, and (iii) into the portal vein through a branch of the splenic vein (0.04 inch i.d.) for subbasal infusion of insulin. All cannulae were tunneled s.c. and exteriorized at the back of the neck. They were filled with heparin $(1000$ $\mathrm{U} / \mathrm{ml}$, Hepalean; Organon Canada, Toronto, ON, Canada) and were maintained patent by flushing frequently with saline. All procedures were performed in accordance with the Canadian Council of Animal Care standards and were approved by the Animal Care Committee of the University of Toronto. Dogs were fed once daily with a combined diet of $15 \mathrm{~g} / \mathrm{kg}$ dog chow (Ralston Purina Canada, Mississauga, ON, Canada) and $500 \mathrm{~g}$ beef chunks (Canada Packers, Inc., Toronto, ON, Canada). Pancreatic enzymes were supplemented (Cotazym; Organon). Diabetes was treated with a once daily s.c. injection of regular (4-15 $\mathrm{U}$ ) and NPH (8-30 U) porcine insulin (Eli Lilly and Company, Indianapolis, IN, USA). Only dogs with at least 5 days of relatively well-controlled diabetes (glycosuria $<1 \%$ ) and the absence of diarrhea and visible steatorrhea were used for experimental studies. 


\section{Experimental protocol}

Twelve experiments were carried out in seven conscious dogs 1-6 weeks after pancreatectomy. Insulin was withdrawn for at least $24 \mathrm{~h}$, and food was withdrawn $18 \mathrm{~h}$ before experiments. On the day of the study, an intraportal infusion of insulin $(3.3 \mathrm{mU} / \mathrm{kg}$ per min) was started and gradually reduced until moderate hyperglycemic levels were reached $(\sim 175 \mathrm{mg} / \mathrm{dl})$. These levels were maintained by infusing intraportal insulin at a constant sub-basal rate $(0 \cdot 19 \pm 0.05 \mathrm{mU} / \mathrm{kg}$ per $\mathrm{min})$. This constant intraportal insulin infusion was maintained throughout the experiment. In depancreatized dogs, it is not necessary to infuse glucagon, as the dog's stomach mucosa secretes normal amounts of glucagon that compensate for the lack of pancreatic glucagon. When plasma glucose decreased below $250 \mathrm{mg} / \mathrm{dl}$, a primed $(70 \mu \mathrm{Ci})$ continuous infusion $(0.5 \mu \mathrm{Ci} / \mathrm{min})$ of HPLC-purified $50 \%$ tracer mixture of $\left[2-{ }^{3} \mathrm{H}\right]-$ and $\left[6-{ }^{3} \mathrm{H}\right]$ glucose (New England Nuclear, Boston, MA, USA) was started and continued for at least $120 \mathrm{~min}$ for tracer equilibration before the $30 \mathrm{~min}$ basal blood sampling period. At time $=0$, either human recombinant IGF-I (KabiPharmacia Peptide Hormones, Stockholm, Sweden) or insulin prepared in a saline vehicle containing approximately $4 \%(\mathrm{v} / \mathrm{v})$ of the dog's own plasma was administered peripherally through a separate catheter. The total dose of IGF-I was $67 \cdot 8 \mu \mathrm{g} / \mathrm{kg}$ $(29 \cdot 1 \mu \mathrm{g} / \mathrm{kg}$ bolus plus $0 \cdot 215 \mu \mathrm{g} / \mathrm{kg}$ per min; $n=5)$ and the total dose of insulin was $49.5 \mathrm{mU} / \mathrm{kg}(9 \mathrm{mU} / \mathrm{kg}$ bolus plus $0.45 \mathrm{mU} / \mathrm{kg}$ per min; $n=7$ ) each infused for $180 \mathrm{~min}$. On a molar basis, the dose of IGF-I was $12 \cdot 2$ higher than that of insulin. This low dose of IGF-I was within the $40-80 \mu \mathrm{g} / \mathrm{kg}$ range shown to be well tolerated in clinical trials (RINDS 1996a). Equal potency of the hormone doses on whole body glucose metabolism was chosen based on previous studies (Giacca et al. 1990, 1994) and pilot experiments, which showed similar steady-state glucose requirements with IGF-I/insulin. During the infusion of IGF-I or insulin, plasma glucose was clamped at the initial hyperglycemic levels by adjusting the glucose infusion (Dextrose 50\% (w/v); Abbott, Montreal, PQ, Canada), step-wise, based on the results of plasma glucose determinations obtained every $5 \mathrm{~min}$. An aliquot of the $50 \%$ tracer mixture was added to the glucose infusate in order to minimize changes in plasma glucose specific activity during the experiment (Fisher et al. 1996). The specific activity of the glucose infusate $\left(\mathrm{SA}_{\text {Ginf }}\right)$ was calculated based on estimations of the parameters in Finegood's formula (Finegood et al. 1988), modified to allow for incomplete suppression of GP (Giacca et al. 1992): $\mathrm{SA}_{\mathrm{Ginf}}=\mathrm{I}$. $\left[\left(\operatorname{Ginf}_{\mathrm{ss}} / \mathrm{Ra}_{\mathrm{b}}\right)-\mathrm{F}\right] /\left(\mathrm{Ginf}_{\mathrm{ss}}\right.$. BW $)$, where $\mathrm{SA}_{\text {Ginf }}$ is the specific activity of glucose infusate, $\mathrm{I}$ is the constant tracer infusion rate, Ginf $\mathrm{ss}_{\mathrm{s}}$ is the steady-state glucose infusion rate, $\mathrm{Ra}_{\mathrm{b}}$ is the basal rate of appearance of glucose, BW is the body weight, $\mathrm{F}$ (fractional suppression $)=\left(\mathrm{Ra}_{\mathrm{b}}-\mathrm{Ra}_{\mathrm{ss}}\right) / \mathrm{Ra}_{\mathrm{b}}$, and $\mathrm{Ra}_{\mathrm{ss}}$ is the steady- state endogenous GP. The following initial estimates were employed; $\mathrm{Ra}_{\mathrm{b}}=3.5 \mathrm{mg} / \mathrm{kg}$ per min, $\mathrm{Ra}_{\mathrm{ss}}=0.5 \mathrm{Ra}_{\mathrm{b}}$, $\operatorname{Ginf}_{\mathrm{ss}}=4 \mathrm{mg} / \mathrm{kg}$ per min. $\mathrm{Ra}_{\mathrm{b}}$ was the mean basal GP under identical basal conditions (Giacca et al. 1992, 1994), $\mathrm{Ra}_{\mathrm{ss}}$ and $\mathrm{Ginf}_{\mathrm{ss}}$ were estimated from pilot experiments.

Blood samples for plasma glucose specific activity were taken every 10 to $15 \mathrm{~min}$, and blood samples for metabolites and hormones every 20 to $30 \mathrm{~min}$.

\section{Laboratory assays}

Plasma glucose concentration was measured in duplicate using a Beckman Glucose Analyzer 2 (Beckman, Fullerton, CA, USA). The RIA for total IGF-I in serum (coefficient of variation 10\%) was performed on samples extracted with acid-ethanol and using a polyclonal antibody. Insulin and glucagon were assayed by RIA (coefficient of variation, 12 and 15\% respectively); free fatty acid (FFA) by a radiochemical technique; and lactate, pyruvate, alanine, glycerol and beta-hydroxybutyrate by enzymatic fluorometric methods as described previously (Giacca et al. 1990).

For determination of $\left[2-{ }^{3} \mathrm{H}\right]-$ and $\left[6-{ }^{3} \mathrm{H}\right]$ glucose specific activities, centrifuged plasma was deproteinized with $\mathrm{Ba}(\mathrm{OH})_{2}$ and $\mathrm{ZnSO}_{4}$, and passed through anion and cation exchange resins (Ag 2-X8 and $\mathrm{Ag} 50 \mathrm{~W}-\mathrm{X} 8$; Bio-Rad Laboratories, Richmond, CA, USA) to remove labeled glucose metabolites. An aliquot of the eluate was then evaporated to dryness to eliminate tritiated water and counted for total radioactivity of both $\left[6-{ }^{3} \mathrm{H}\right]-$ and $\left[3-{ }^{3} \mathrm{H}\right]$ glucose. The radioactivity of $\left[6-{ }^{3} \mathrm{H}\right]$ glucose was determined with the dimedone precipitation technique (Dunn et al. 1957). The radioactivity of $\left[2-{ }^{3} \mathrm{H}\right]$ glucose was calculated as the difference between total radioactivity and that of $\left[6-{ }^{3} \mathrm{H}\right]$ glucose, corrected for recovery $(98 \pm$ $1 \%)$. Aliquots of the infused mixture of $\left[6-{ }^{3} \mathrm{H}\right]-$ and $\left[2-{ }^{3} \mathrm{H}\right]$ glucose and of the labeled glucose infusate were assayed together with the plasma samples.

\section{Calculations}

GP and glucose output were calculated as the endogenous rate of appearance measured with $\left[6-{ }^{3} \mathrm{H}\right]$ glucose and $\left[2-{ }^{3} \mathrm{H}\right]$ glucose respectively; glucose cycling was calculated from the difference between glucose output and production; glucose utilization was calculated as the rate of disappearance measured with $\left[6-{ }^{3} \mathrm{H}\right]$ glucose $(\mathrm{Rd})$. A modified one-compartmental model was used to account for the exogenously infused mixture of labeled and unlabeled glucose (Finegood et al. 1988). With this method, the monocompartmental assumption becomes minor because the non-steady-state component of Steele's equation is close to zero. Data were smoothed according to the 'optimal-segments method' (Finegood \& Bergman 1983). Rd corresponds to glucose utilization, and plasma clearance rate of glucose ( $\mathrm{Rd} /$ glycemia) to glucose 
metabolic clearance rate because plasma glucose levels were below the renal threshold for glucose in dogs (Bjorkman et al. 1988). During the clamp, exogenous glucose infusion (Ginf) was subtracted from the total rate of glucose appearance to solve for endogenous GP.

\section{Statistical analysis}

Statistical analysis was performed with the Statistical Analysis System (SAS, Cary, NC, USA) package on an IBM compatible personal computer. ANOVA for repeated measurements was used to test for differences between experimental groups during two experimental periods (basal: from -30 to $0 \mathrm{~min}$, and clamp: from 0 to $180 \mathrm{~min}$ ). In addition, where indicated, values for the two treatment groups are compared during the first and last hours of the clamp. ANOVA was also carried out to test for differences between experimental periods (basal and clamp) for each of the two treatments. Data are expressed as means \pm S.E. and unless otherwise noted, significance was presumed at $P<0 \cdot 05$.

\section{Results}

In the basal period during subbasal portal insulin infusion but before any peripheral hormone infusion, insulin levels were similar at $6.6 \pm 0.5$ and $7 \cdot 8 \pm 0.4 \mu \mathrm{U} / \mathrm{ml}$ for both the insulin and IGF-I groups respectively (Fig. 1, top panel). With peripheral insulin infusion during the clamp, insulin levels rose 4-fold. With IGF-I infusion, insulin levels remained at basal levels, indicating that IGF-I has no effect on insulin clearance (the portal insulin infusion was continued during the clamp). In the basal period, the IGF-I levels were not significantly different for the insulin and IGF-I treated groups (Fig. 1, middle panel). In response to insulin infusion, the IGF-I levels declined during the clamp $(P<0 \cdot 05)$. In spite of the bolus of IGF-I given, the IGF-I levels rose only gradually, becoming significantly greater than basal levels $(P<0 \cdot 01)$ only during the last $2 \mathrm{~h}$ of the clamp. In the basal period before any peripheral hormone infusion, plasma glucagon levels were similar. During the clamp, glucagon levels (Fig. 1, bottom panel) fell $(P<0 \cdot 05)$ similarly with both insulin and IGF-I treatments.

The subbasal infusion of insulin maintained preclamp glycemia constant at $175 \pm 3$ and $173 \pm 1 \mathrm{mg} / \mathrm{dl}$ before infusion of insulin or IGF-I (Fig. 2, top panel). During both the insulin and IGF-I infusions, plasma glucose remained clamped ( $P=\mathrm{NS}$, basal vs clamp) at this level of hyperglycemia. The plasma specific activity of $\left[6-{ }^{3} \mathrm{H}\right]$ glucose decreased slightly and similarly with both the insulin $(10 \pm 2 \%$ by the last hour of the clamp) and IGF-I $(16 \pm 2 \%)$ infusions, but remained within $20 \%$ of basal at all times (Fig. 2, middle panel). The fall in
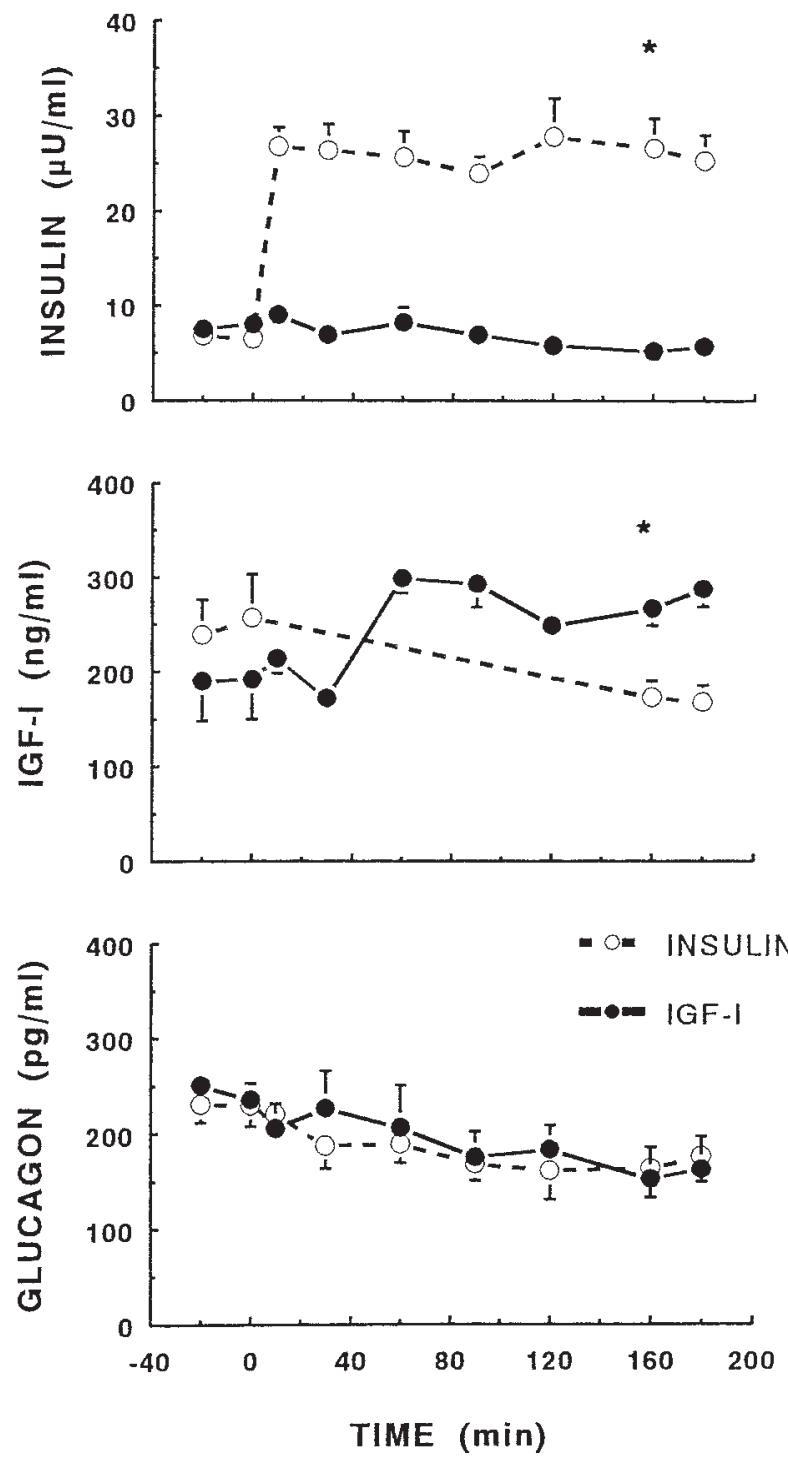

Figure 1 Plasma levels of insulin (top panel), total IGF-I (middle panel) and glucagon (bottom panel). Measurements were taken before and during peripheral infusion of IGF-I $(29 \cdot 1 \mu \mathrm{g} / \mathrm{kg}$ bolus plus $0.215 \mu \mathrm{g} / \mathrm{kg}$ per min infusion; $n=5)$ or insulin $(9 \mathrm{mU} / \mathrm{kg}$ bolus plus $0.45 \mathrm{mU} / \mathrm{kg}$ per min; $n=7$ ) in moderately hyperglycemic depancreatized dogs infused with subbasal intraportal insulin $(0 \cdot 19 \pm 0.05 \mathrm{mU} / \mathrm{kg}$ per $\mathrm{min})$. A glucose clamp was maintained by infusing a mixture of labeled and unlabeled glucose, as described in the text. Data are means \pm S.E. ${ }^{*} P<0 \cdot 001$ IGF-I vs insulin during the clamp.

$\left[2-{ }^{3} \mathrm{H}\right]$ glucose specific activity also remained within $25 \%$ of basal for both treatments (Fig. 2, bottom panel).

The glucose infusion (Fig. 3, top panel) required to maintain glycemia rose briskly during the first hour of the clamp to a greater extent in response to IGF-I vs insulin infusion $(3 \cdot 5 \pm 0 \cdot 4$ vs $2 \cdot 5 \pm 0 \cdot 2 \mathrm{mg} / \mathrm{kg}$ per min, $P<0 \cdot 05)$. However, by the last hour of the clamp, glucose infusion 

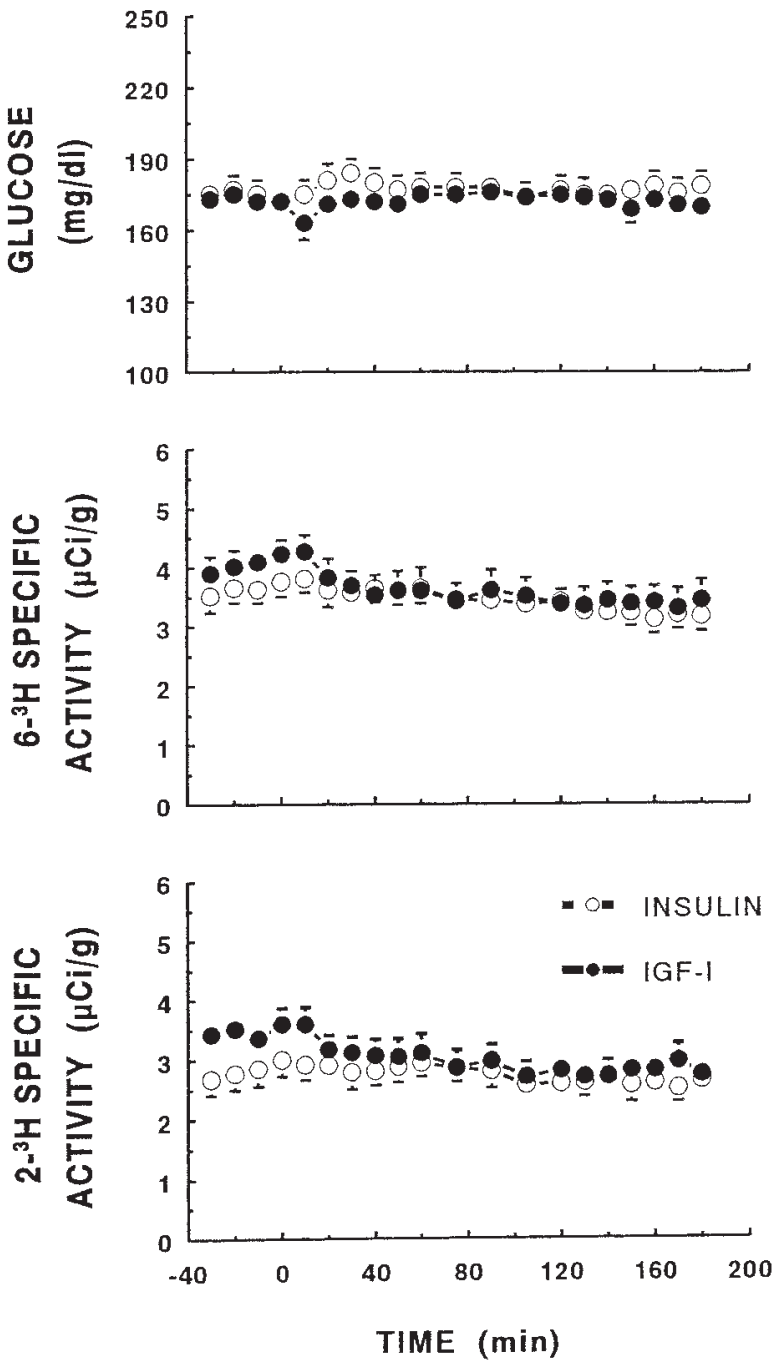

Figure 2 Plasma levels of glucose (top panel), $\left[6-{ }^{3} \mathrm{H}\right]$ glucose specific activity (middle panel) and $\left[2-{ }^{3} \mathrm{H}\right]$ glucose specific activity (bottom panel) before and during IGF-I or insulin infusion. The experimental design is outlined in the legend to Fig. 1. Data are means \pm S.E.

values were similar (insulin $4 \cdot 2 \pm 0 \cdot 3$; IGF-I $3 \cdot 6 \pm$ $0 \cdot 3 \mathrm{mg} / \mathrm{kg}$ per $\min , P=\mathrm{NS}$ ). GP rates (Fig. 3 , middle panel) during the basal period were similar $(3 \cdot 5 \pm 0 \cdot 2$ and $3 \cdot 4 \pm 0 \cdot 1 \mathrm{mg} / \mathrm{kg}$ per $\mathrm{min}, P=\mathrm{NS}$, insulin and IGF-I respectively) and were suppressed in a comparable fashion during the clamp $(1.5 \pm 0 \cdot 1$ and $1.6 \pm 0 \cdot 1 \mathrm{mg} / \mathrm{kg}$ per min, $P=\mathrm{NS}$ ), which represent suppressions of $56 \pm 2 \%$ for insulin and $54 \pm 3 \%$ for IGF-I. Glucose output (as measured with $\left[2-{ }^{3} \mathrm{H}\right]$ glucose; Table 1) was also suppressed equally ( $42 \pm 2$ and $40 \pm 2 \%, P=\mathrm{NS}$ ) with insulin and IGF-I (Table 1). Hepatic glucose cycling (flux between glucose and glucose-6-phosphate), as calculated from the difference between glucose output and production, did not change in response to insulin or IGF-I
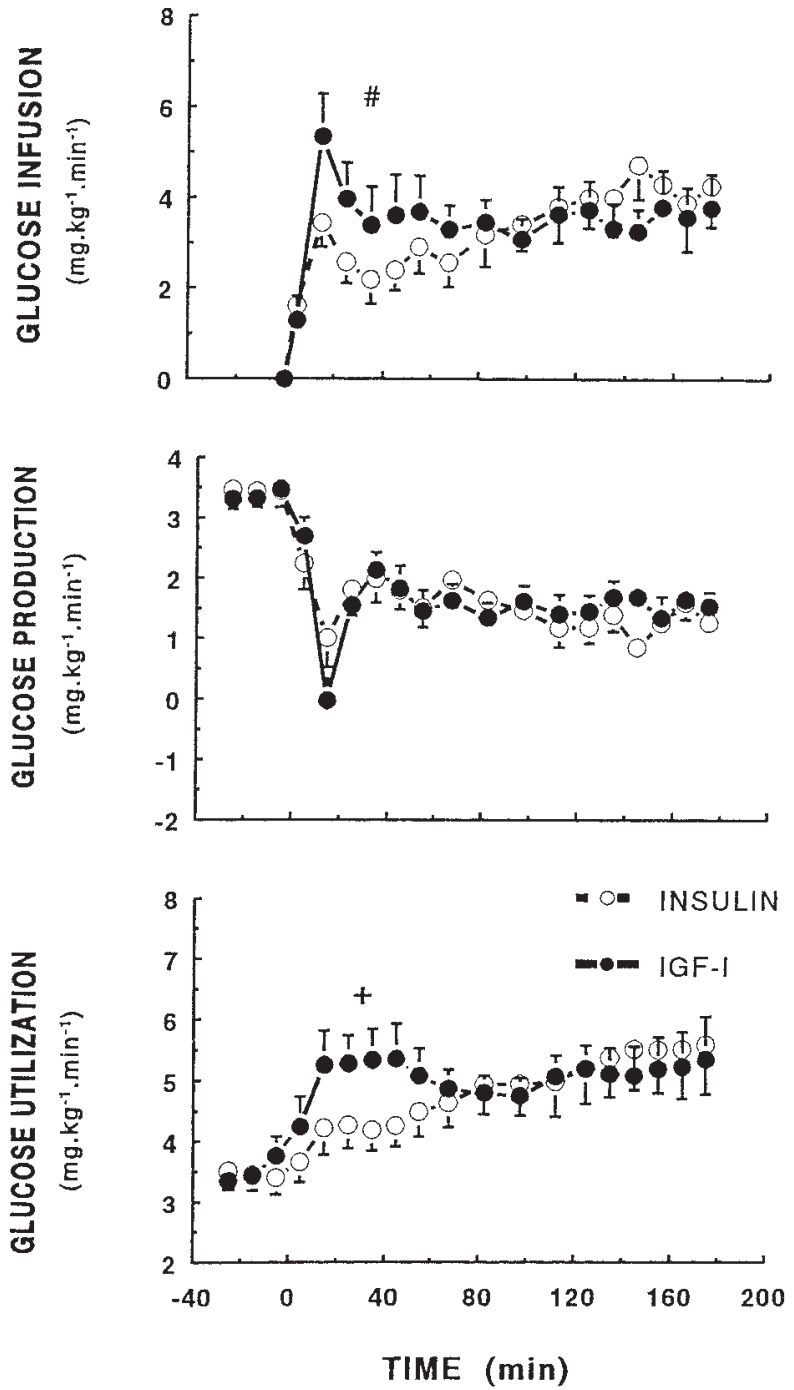

Figure 3 Glucose infusion rates (top panel), GP (middle panel) and glucose utilization (bottom panel) before and during IGF-I or insulin infusion. The experimental design is outlined in the legend to Fig. 1. Data are means \pm S.E.. $\# P<0.05$ IGF-I vs insulin during the first hour of the clamp. $+P<0 \cdot 01$ IGF-I vs insulin during the first hour of the clamp.

infusion (Table 1). Glucose utilization (Fig. 3, bottom panel) was similar in the basal period (insulin $3 \cdot 5 \pm 0 \cdot 2$; and IGF-I $3.5 \pm 0 \cdot 1 \mathrm{mg} / \mathrm{kg}$ per min, $P=\mathrm{NS}$ ) and rose significantly higher $(P<0 \cdot 01)$ during the first hour of the clamp with IGF-I $(5 \cdot 1 \pm 0 \cdot 2 \mathrm{mg} / \mathrm{kg}$ per min) than with insulin $(4 \cdot 2 \pm 0 \cdot 2 \mathrm{mg} / \mathrm{kg}$ per min) infusion, but was similar by the third hour of the clamp (insulin $5 \cdot 5 \pm 0 \cdot 3$; and IGF-I $5 \cdot 2 \pm 0 \cdot 2 \mathrm{mg} / \mathrm{kg}$ per min, $P=\mathrm{NS}$ ). In a parallel fashion, glucose clearance rates (not shown) were similar in the insulin and IGF-I group in the basal period $(2 \cdot 0 \pm 0 \cdot 1$ and $2 \cdot 0 \pm 0 \cdot 1 \mathrm{ml} / \mathrm{kg}$ per min, $P=\mathrm{NS})$ and rose higher with IGF-I $(3 \cdot 0 \pm 0 \cdot 1)$ than insulin $(2 \cdot 4 \pm 0 \cdot 1 \mathrm{ml} / \mathrm{kg}$ per 
Table 1 Glucose output and cycling ( $\mathrm{mg} / \mathrm{kg}$ per min, means \pm S.E.) in the basal period and during insulin $(n=7)$ and IGF-I infusions $(n=5)$

\begin{tabular}{|c|c|c|c|c|}
\hline & \multicolumn{2}{|l|}{ Insulin } & \multicolumn{2}{|l|}{ IGF-I } \\
\hline & Basal & $0-180 \mathrm{~min}$ & Basal & $0-180 \mathrm{~min}$ \\
\hline Glucose output & $4 \cdot 8 \pm 0 \cdot 3$ & $2 \cdot 8 \pm 0 \cdot 1^{*}$ & $4 \cdot 4 \pm 0 \cdot 3$ & $2 \cdot 6 \pm 0 \cdot 1^{*}$ \\
\hline Glucose cycling & $1 \cdot 3 \pm 0 \cdot 2$ & $1 \cdot 3 \pm 0 \cdot 1$ & $1 \cdot 0 \pm 0 \cdot 3$ & $1 \cdot 0 \pm 0 \cdot 1$ \\
\hline
\end{tabular}

min, $P<0 \cdot 01)$ during the first hour of the clamp but were similar (insulin $3 \cdot 1 \pm 0 \cdot 2$; and IGF-I $3 \cdot 0 \pm 0 \cdot 1 \mathrm{ml} / \mathrm{kg}$ per $\min , P=\mathrm{NS}$ ) by the last hour of the clamp.

Plasma FFA and glycerol levels (Fig. 4, top and middle panels) were similar in the basal period in both insulin and IGF-I groups (FFA: $1190 \pm 70$ and $1350 \pm 150 \mu \mathrm{M}$, $P=\mathrm{NS}$; glycerol: $(105 \pm 5$ and $121 \pm 11 \mu \mathrm{M}, P=\mathrm{NS})$ and were suppressed to a similar extent (FFA: $580 \pm 50$ and $560 \pm 50 \mu \mathrm{M}, P=\mathrm{NS}$; glycerol: $72 \pm 4$ and $78 \pm 4 \mu \mathrm{M}$, $P=\mathrm{NS}$ ) with insulin and IGF-I infusions. Plasma lactate (Fig. 4, bottom panel) was similar in the basal period $(700 \pm 70$ and $740 \pm 50 \mu \mathrm{M}, P=\mathrm{NS}$, insulin and IGF-I respectively) and increased similarly with insulin and IGF-I infusions $(850 \pm 50$ and $950 \pm 34 \mu \mathrm{M}, P=\mathrm{NS})$.

Plasma alanine (Fig. 5, top panel) and betahydroxybutyrate levels (Fig. 5, bottom panel) were similar during the basal period and were suppressed to a similar extent during the clamp. Pyruvate levels (Fig. 5, middle panel) were also similar in the basal period in both insulin and IGF-I groups and rose equally during the clamp.

\section{Discussion}

Low doses of IGF-I (40-80 $\mu \mathrm{g} / \mathrm{kg})$ are being tested in clinical trials for the treatment of diabetes and other insulin-resistant states (Bach et al. 1994, Cusi \& DeFronzo 1995, RINDS 1996a, b, Acerini 1997, Carroll 1997, Quattrin 1997) because high doses of IGF-I $(100-250 \mu \mathrm{g} / \mathrm{kg})$ have been associated with significant adverse side effects (Schalch et al. 1993, Jabri et al. 1994, Usala et al. 1994, Moses et al. 1996). The relative therapeutic efficacy of low-dose IGF-I vs insulin administration has been questioned. We show here that low-dose IGF-I administration $(67 \cdot 8 \mu \mathrm{g} / \mathrm{kg})$ can significantly suppress GP (54\%) and stimulate glucose utilization (49\%), and effectively suppress lipolysis in hyperglycemic depancreatized dogs. These low doses of IGF-I, however, have no selective advantage over the administration of low-dose insulin on the acute regulation of glucose turnover and lipolysis.

In this study, there was a much greater bolus-toinfusion ratio for IGF-I than insulin in order to saturate the IGF-binding proteins and attempt to prevent the insulin levels from plateauing much earlier than the IGF-I levels. Despite these efforts, the rise in IGF-I was delayed compared to the prompt rise and plateau seen with insulin administration. Interestingly, it was during this first hour of the clamp when, although there was no detected increase
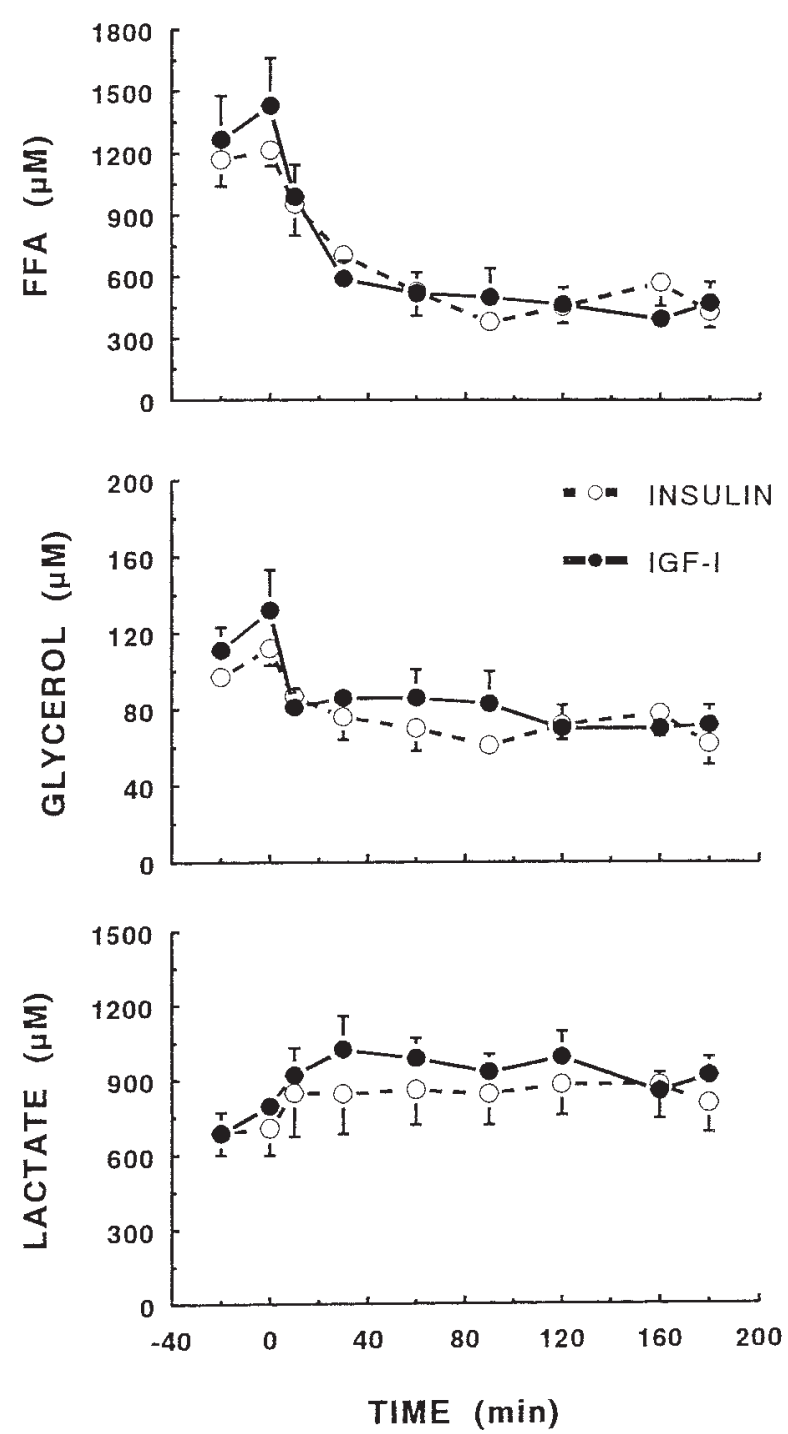

Figure 4 Plasma levels of FFA (top panel), glycerol (middle panel) and lactate (bottom panel) before and during IGF-I or insulin infusion. The experimental design is outlined in the legend to Fig. 1. Data are means \pm S.E. 

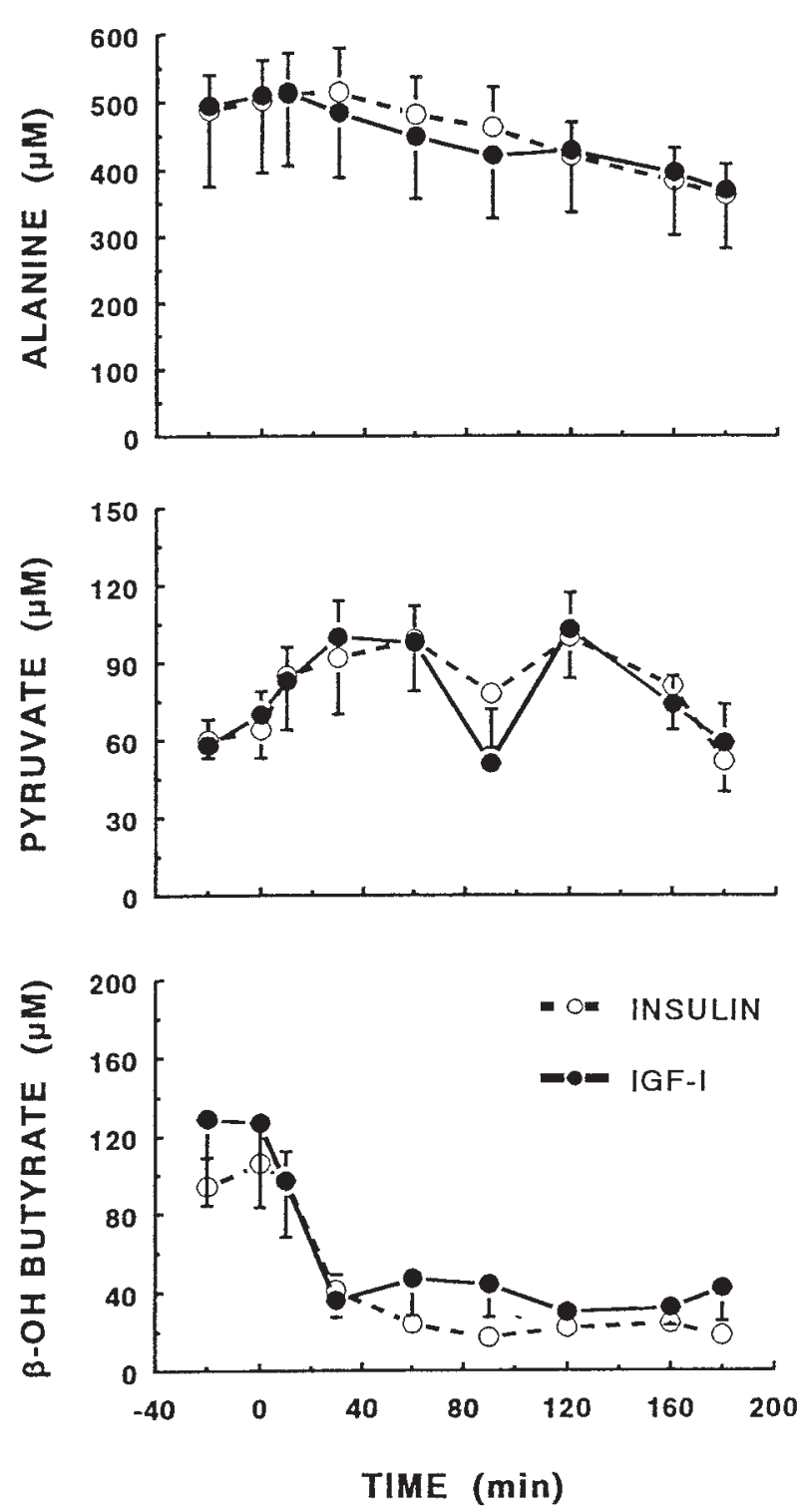

Figure 5 Plasma levels of alanine (top panel), pyruvate (middle panel) and beta-hydroxybutyrate (bottom panel) before and during IGF-I or insulin infusion. The experimental design is outlined in the legend to Fig. 1. Data are means \pm S.E.

in total IGF-I levels, the increment in glucose utilization and glucose infusion was significantly higher for IGF-I than insulin protocols. This suggests that the rapid i.v. bolus of IGF-I increased the free IGF-I levels (not assessed in our assay) over the first hour of the clamp, which allowed for the enhanced stimulation of glucose utilization. Consistent with this hypothesis is the observation that after an i.v. IGF-I bolus, most of the IGF-I remains free and not bound to IGF-binding proteins until $1 \mathrm{~h}$ after administration (Zapf et al. 1986). The fact that equal metabolic effects were achieved by only a 2 -fold elevation of total
IGF-I and a 4-fold elevation of insulin levels is also consistent with the notion that the metabolic effects of IGF-I are determined by the free IGF-I levels.

By experimental design, the doses of IGF-I and insulin were chosen based on their equipotent glucose lowering ability (Giacca et al. 1990). There was a 50\% stimulation of glucose utilization and a $\sim 50 \%$ suppression of GP with both hormones. We previously noted that approximately 2 -fold higher doses of IGF-I $(106.5 \mu \mathrm{g} / \mathrm{kg})$ and insulin stimulated glucose utilization by $\sim 120 \%$ while suppressing GP by $\sim 65 \%$ (Giacca et al. 1994). Thus, the stimulation of glucose utilization was linearly dependent on the hormone dose within this range of infusions, whereas the suppression of GP was not. The fact that GP remained as sensitive to the suppressive effects of low-dose IGF-I as that of insulin is somewhat surprising given the paucity of hepatic IGF-I receptors (Caro et al. 1988), but is in accordance with the concept that both IGF-I and insulin may suppress hepatic GP indirectly, i.e. in proportion to peripheral levels, rather than directly, i.e. in proportion to hepatic sinusoidal levels, in hyperglycemic depancreatized dogs. Our previous studies confirm that peripheral insulinemia predominantly determines the suppression of GP in hyperglycemic depancreatized dogs (Giacca et al. $1992,1999)$. The mechanism by which peripheral concentrations of insulin and/or IGF-I may suppress GP might be via suppression of glucagon (Giacca et al. 1992, 1997, Lewis et al. 1998), suppression of FFA (Rebrin et al. 1996, Lewis et al. 1997, Sindelar et al. 1997) and gluconeogenic precursors (Giacca et al. 1992, Sindelar et al. 1996). Interestingly, the initial suppression of GP was very rapid, consistent with the IGF-I/insulin bolus being given. An equally rapid suppression of FFA was seen.

We have previously shown that under conditions of equipotency between the two hormones (based on glucose lowering) and declining glycemia, low-dose IGF-I is less effective in suppressing GP but more effective in stimulating glucose utilization than insulin (Giacca et al. 1990). In the present study, the differential effects of IGF-I and insulin were limited to a greater glucose utilization with IGF-I, likely in muscle, and occurred at a time (first hour of the clamp) when IGF-I was more potent than insulin (greater glucose infusion rate), presumably because free IGF-I rose to a greater extent than insulin. However, when IGF-I and insulin were equipotent (same glucose infusion rate), the effects of IGF-I and insulin on GP and utilization were equal. The primary difference between our previous study and our current study is the maintenance of a hyperglycemic state in these depancreatized dogs. Hyperglycemia per se may have masked some of the differential effects between IGF-I and insulin (Giacca et al. 1994). Hyperglycemia can suppress GP (Sacca et al. 1979, Bell et al. 1986) by inhibiting glycogenolysis more than gluconeogenesis (Rossetti et al. 1993). Since insulin's direct effect on suppressing GP consists primarily of inhibiting glycogenolysis (Sindelar et al. 1996), the 
diminished rates of glycogenolysis during hyperglycemia would tend to limit insulin's direct effects. Therefore, the maintenance of hyperglycemia in the current study may increase the dependence of GP on indirect, peripheral actions of insulin and IGF-I. To support this hypothesis we have recent data suggesting that the acute correction of hyperglycemia can restore the direct or hepatic effect of insulin on GP in depancreatized dogs (Gupta et al. 1998). One could also argue that prevailing level of glycemia could have altered the concentrations of IGF-binding proteins (Baxter 1991). Thus, hyperglycemia may affect IGF-I action by means of regulating IGF-binding protein levels which might account for some of the discrepancies between this and our previous study (Giacca et al. 1990).

Since a control group (i.e. saline infusion) was not included in this study, it could be argued that some of the changes in metabolites and glucose turnover during the 180 min clamp period may have been due to the prolongation of fasting or the failure to reach steady-state during the $120 \mathrm{~min}$ tracer equilibration period. These two sources of variability might confound our results comparing IGF-I and insulin protocols. We have previously addressed these issues with a separate group of depancreatized dogs under identical conditions of hyperglycemia maintained with subbasal intraportal insulin infusions (Fisher et al. 1996). We observed that, consistent with the loss of glucose-insulin feedback in these depancreatized dogs, there was a slight tendency for GP to decrease (less than 20\%) although glucose utilization did not change significantly from basal conditions over $180 \mathrm{~min}$ in this control group (Fisher et al. 1996). Thus, in the present study we recognize the possibility that a small portion of the 55\% GP suppression attributed to insulin or IGF-I administration during the $3 \mathrm{~h}$ clamp may in part be due to the prolongation of fasting.

Increased glucose cycling is an early and sensitive indicator of altered hepatic glucose metabolism in type 2 diabetes (Efendic et al. 1988). In this study, low-dose IGF-I or insulin failed to reduce glucose cycling under conditions of hyperglycemia. We have previously shown that the simultaneous correction of both hyperglycemia and hypoinsulinemia may be necessary for the correction of elevated glucose cycling in diabetes (Shi et al. 1994).

The effects of IGF-I on FFA metabolism have been conflicting. High doses of IGF-I have been shown to suppress FFA levels, oxidation and turnover (Guler et al. 1987, Laager et al. 1993, Boulware et al. 1994, Usala et al. 1994). Given the reduced expression of IGF-I receptors on the adipocyte (Zapf et al. 1981, Sinha et al. 1989), it was speculated that IGF-I suppresses lipolysis via its crossreactivity with the insulin receptor, thus requiring high IGF-I levels to mediate effects on the adipocyte. Thus, it was somewhat expected when low-dose IGF-I administration was found to have no effect on FFA metabolism (Mauras et al. 1992, Elahi et al. 1993, Laager et al. 1993). In the current study, it was surprising to note that low-dose IGF-I induced suppression of FFA levels by $50 \%$ and glycerol by $30 \%$. The reason for the anti-lipolytic effect seen in our low-dose IGF-I study as compared to others may be multifactorial and related to IGF-binding proteins, the disturbed growth hormone-IGF axis, the hyperglycemic state, or our model of diabetes. Indeed, the anti-lipolytic effects of low-dose IGF-I may be revealed in the depancreatized dog due to absence of confounding effects of IGF-I-mediated suppression of endogenous insulin secretion. We speculate that the failure of low-dose IGF-I to demonstrate anti-lipolytic effects in previous studies (Mauras et al. 1992, Elahi et al. 1993, Laager et al. 1993) may be related to conflicts with the lipolytic effects of a concomitant IGF-I-mediated suppression of insulin secretion.

In summary, in our model of type 1 diabetes, similar to our previous study with high-dose IGF-I, low-dose IGF-I had the same effects as additional insulin in suppressing GP and lipolysis and stimulating glucose utilization during hyperglycemia and subbasal insulin infusion. We conclude that: (i) differential effects of IGF-I and insulin are not dose-related; and (ii) low-dose IGF-I infusion, despite showing significant effects on glucose turnover and lipolysis, does not have preferential metabolic effects compared to insulin, at least when hyperglycemia is present and endogenous insulin secretion is absent.

\section{Acknowledgements}

This work was supported by grant no. MT2197 from the Medical Research Council of Canada. We thank Ms D Bilinski, M VanDelangeryt and L Lam for their excellent technical assistance, Dr A Skottner and Kolsi Pharmacia, Stockholm, for the generous gift of IGF-I and the IGF-I assay, and the Core Laboratory of the Banting and Best Diabetes Centre of the University of Toronto for the analyses of lactate, pyruvate, alanine, glycerol and betahydroxybutyrate.

\section{References}

Acerini CL, Patton CM, Savage MO, Kernell S, Westphal O \& Dunger DB 1997 Randomized placebo-controlled trial of human recombinant insulin-like growth factor I plus intensive insulin therapy in adolescents with insulin-dependent diabetes mellitus. Lancet 350 1199-1204.

Bach MA, Chin E \& Bondy CA 1994 The effects of subcutaneous insulin-like growth factor-I infusion in insulin-dependent diabetes mellitus. Journal of Clinical Endocrinology and Metabolism 79 1040-1045

Baxter RC 1991 Physiological roles of IGF binding proteins. In Modern Concepts of Insulin-Like Growth Factors, pp 371-380. Ed. EM Spencer. New York: Elsevier.

Bell PM, Firth RG \& Rizza RA 1986 Effects of hyperglycemia on glucose production and utilization in humans. Measurements with $\left[2-{ }^{3} \mathrm{H}\right]-,\left[3-{ }^{3} \mathrm{H}\right]-$, and $\left[6-^{14} \mathrm{C}\right]$-glucose. Diabetes 35 642-648. 
Bjorkman O, Miles P, Wasserman D, Lickley HLA \& Vranic M 1988 Regulation of glucose turnover in pancreatectomized, totally insulin deficient dogs: effects of beta-adrenergic blockade. Journal of Clinical Investigation 81 1759-1767.

Bondy CA, Underwood LE, Clemmons DR, Guler H-P, Bach MA \& Skarulis M 1994 Clinical uses of insulin-like growth factor I. Annals of Internal Medicine 120 592-601.

Boulware SD, Tamborlane WV, Rennert NJ, Gesundheit N \& Sherwin RS 1994 Comparison of the metabolic effects of recombinant human insulin-like growth factor-I and insulin. Dose-response relationship in healthy young and middle-aged adults. Journal of Clinical Investigation 93 1131-1139.

Caro JF, Poulos J, Ittoop O, Pories WJ, Flickinger EG \& Sinha MK 1988 Insulin-like growth factor I binding in hepatocytes from human liver hepatoma, and normal, regenerating, and fetal rat liver. Journal of Clinical Investigation 81 976-981.

Carroll PV, Umpleby M, Ward GS, Imuere S, Alexander E, Dunger D, Sonksen PH \& Russell-Jones DL 1997 RhIGF-I administration reduces insulin requirements, decreases growth hormone secretion, and improves the lipid profile in adults with IDDM. Diabetes 46 1453-1458.

Cheetham TD, Jones J, Taylor A, Holly J, Matthews DR \& Dunger DB 1993 The effects of recombinant insulin-like growth factor I administration on growth hormone levels and insulin requirements in adolescents with type 1 (insulin-dependent) diabetes mellitus. Diabetologia 36 678-681.

Cusi K \& DeFronzo RA 1995 Metabolic effects of treatment with IGF-I in NIDDM. Diabetes 44 (Suppl 1) 157A.

Dunn DF, Friedman B, Maass AR, Reich GA \& Weinhouse S 1957 Effects of insulin on glucose entry and removal in normal dogs. Journal of Biological Chemistry 225 225-237.

Efendic S, Karlander S \& Vranic M 1988 Mild type II diabetes markedly increases glucose cycling in the postabsorptive state and during glucose infusion irrespective of obesity. Journal of Clinical Investigation 81 1953-1961.

Elahi D, McAloon-Dyke M, Fukagawa NK, Sclater AL, Wong GA, Shannon RP, Minaker KL, Miles JM, Rubenstein AH, Vandepol CJ, Guler H-P, Good WR, Seaman JJ \& Wolfe RR 1993 Effects of recombinant human IGF-I on glucose and leucine metabolism in humans. American Journal of Physiology 265 E831-E838.

Finegood DT \& Bergman RN 1983 Optimal segments: a method for smoothing tracer data to calculate metabolic fluxes. American Journal of Physiology 244 E472-E479.

Finegood DT, Bergman RN \& Vranic M 1988 Modeling error and apparent isotope discrimination confound estimation of endogenous glucose production during euglycemic glucose clamps. Diabetes 37 $1025-1034$.

Fisher SJ, Shi ZQ, Lickley HLA, Efendic S, Vranic M \& Giacca A 1996 A moderate decline in specific activity does not lead to an underestimation of hepatic glucose production during a glucose clamp. Metabolism 45 587-593.

Giacca A, Gupta R, Efendic S, Hall K, Skottner A, Lickley HLA \& Vranic M 1990 Differential effects of IGF-I and insulin on glucoregulation and fat metabolism in depancreatized dogs. Diabetes 39 340-347.

Giacca A, Fisher S, Shi ZQ, Gupta R, Lickley HLA \& Vranic M 1992 Importance of peripheral insulin levels for insulin-induced suppression of glucose production in depancreatized dogs. Journal of Clinical Investigation 90 1769-1777.

Giacca A, Fisher SJ, Shi ZQ, Gupta R, Lickley HLA, Skottner A, Anderson GH, Efendic S \& Vranic M 1994 Insulin-like growth factor-I and insulin have no differential effects on glucose production and utilization under conditions of hyperglycemia. Endocrinology 134 2251-2258.

Giacca A, Fisher SJ, McCall RH, Shi ZQ \& Vranic M 1997 Direct and indirect effects of insulin in suppressing glucose production in depancreatized dogs: role of glucagon. Endocrinology 138 999-1007.
Giacca A, McCall RH, Chan B \& Shi ZQ 1999 Increased dependence of glucose production on peripheral insulin in diabetic depancreatized dogs. Metabolism 48 153-160.

Guler H-P, Zapf J \& Froesch ER 1987 Short-term metabolic effects of recombinant human insulin-like growth factor I in healthy adults. New England Journal of Medicine 317 137-140.

Gupta N, Sandhu H, Goh T, McCall RH \& Giacca A 1998 Euglycemia acutely restores the direct hepatic effect of insulin on glucose production (GP) in depancreatized dogs. Diabetes $\mathbf{4 7}$ (Suppl 1) A41.

Jabri N, Schalch DS, Schwartz SL, Fischer JS, Kipnes MS, Radnik BJ, Turman NJ, Marcsisin VS \& Guler HP 1994 Adverse effects of recombinant human insulin-like growth factor-I in obese insulinresistant type II diabetic patients. Diabetes 43 369-374.

Janssen JAMJL, Jacobs ML, Derkx FHM, Weber RFA, Van der Lely AJ \& Lamberts SWJ 1997 Free and total insulin-like growth factor I (IGF-I), IGF-binding protein 1 (IGFBP-1) and IGFBP-3 and their relationships to the presence of diabetic retinopathy and glomerular hyperfiltration in insulin-dependent diabetes mellitus. Journal of Clinical Endocrinology and Metabolism 82 2809-2815.

Laager R, Ninnis R \& Keller U 1993 Comparison of the effects of recombinant human insulin-like growth factor-I and insulin on glucose and leucine kinetics in humans. Journal of Clinical Investigation 92 1903-1909.

Lewis GF, Vranic M, Harley P \& Giacca A 1997 Fatty acids mediate the acute extrahepatic effects of insulin on hepatic glucose production in humans. Diabetes 46 1111-1119.

Lewis GF, Vranic M \& Giacca A 1998 Role of free fatty acids and glucagon in the peripheral effect of insulin on glucose production in humans. American Journal of Physiology 275 E177-E186.

Malozowski S \& Stadel B 1994 Risks and benefits of insulin-like growth factor. Annals of Internal Medicine 121549.

Mauras N, Horber FF \& Haymond MW 1992 Low dose recombinant human insulin-like growth factor-I fails to affect protein anabolism but inhibits islet cell secretion in humans. Journal of Clinical Endocrinology and Metabolism 75 1192-1197.

Meyer-Schwickerath R, Pfeiffer A, Blum WF, Freyberger H, Klein M, Losche C, Rollmann R \& Schatz H 1993 Vitreous levels of the insulin-like growth factors I and II, and the insulin-like growth factor binding proteins 2 and 3 , increase in neovascular eye disease. Journal of Clinical Investigation 92 2620-2625.

Moses AC, Young SCJ, Morrow LA, O'Brien M \& Clemmons DR 1996 Recombinant human insulin-like growth factor I increases insulin sensitivity and improves glycemic control in type II diabetes. Diabetes 45 91-100.

Quattrin T, Thrailkill K, Baker L, Litton J, Dwigun K, Rearson M, Poppenheimer M, Giltinan D, Gesundheit N \& Martha P Jr 1997 Dual hormonal replacement with insulin and recombinant human insulin-like growth factor I in IDDM. Effects on glycemic control, IGF-I levels, and safety profile. Diabetes Care 20 374-380.

Rebrin K, Steil GM, Mittelman SD \& Bergman RN 1996 Causal linkage between insulin suppression of lipolysis and suppression of liver glucose output in dogs. Journal of Clinical Investigation $\mathbf{9 8}$ 741-749

RINDS (RhIGF-I in non-insulin dependent diabetes study group) 1996a Safety profiling of rhIGF-I therapy in patients with NIDDM. Diabetes 45 (Suppl 2) 71A.

RINDS (RhIGF-I in non-insulin dependent diabetes study group) $1996 b$ Evidence from a dose-ranging study that recombinant insulin-like growth factor I (RhIGF-I) effectively and safely improves glycemic control in non-insulin dependent diabetes mellitus (NIDDM). Diabetes 45 (Suppl 2) 27A.

Rossetti L, Giaccari A, Barzilai N, Howard K, Sebel G \& Hu M 1993 Mechanism by which hyperglycemia inhibits hepatic glucose production in conscious rats. Implications for the pathophysiology of fasting hyperglycemia. Journal of Clinical Investigation 92 1126-1134. 
Sacca L, Hendler R \& Sherwin RS 1979 Hyperglycemia inhibits glucose production in man independent of changes in glucoregulatory hormones. Journal of Clinical Endocrinology and Metabolism 47 1160-1163.

Schalch DS, Turnman NJ, Marcsisin VS, Heffernan M \& Guler H-P 1993 Short-term effects of human insulin-like growth factor I on metabolic control of patients with type II diabetes mellitus. Journal of Clinical Endocrinology and Metabolism 77 1563-1568.

Shi ZQ, Giacca A, Fisher S, Vidal H, Van de Werve G \& Vranic M 1994 Importance of substrate changes in the decrease of hepatic glucose cycling during insulin infusion and declining glycemia in the depancreatized dog. Diabetes 43 1284-1290.

Shojaee-Moradie F, Umpleby AM, Thomason MJ, Jackson NC, Boroujerdi MA, Sonksen PH, Skottner A \& Jones RH 1995 A comparison of the effects of insulin-like growth factor-I, insulin and combined infusions of insulin and insulin-like growth factor-I on glucose metabolism in dogs. European Journal of Clinical Investigation 25 920-928.

Sindelar DK, Balcom JH, Chu CA, Neal DW \& Cherrington AD 1996 A comparison of the effects of selective increases in peripheral or portal insulin on hepatic glucose production in the conscious dog. Diabetes 45 1594-1604.

Sindelar DK, Chu CA, Rohlie M, Neal DW, Swift LL \& Cherrington AD 1997 The role of fatty acids in mediating the effects of peripheral insulin on hepatic glucose production in the conscious dog. Diabetes 46 187-196.
Sinha MK, Buchanan C, Leggett N, Martin L, Khazanie PG, Dimarchi R, Pories WJ \& Caro JF 1989 Mechanism of IGF-I-stimulated glucose transport in human adipocytes: demonstration of specific IGF-I receptors not involved in stimulation of glucose transport. Diabetes 38 1217-1225.

Usala A-L, Madigan T, Burguera B, Cefalu W, Sinha MK, Powell JG \& Usala SJ 1994 High dose intravenous, but not low dose subcutaneous, insulin-like growth factor-I therapy induces sustained insulin sensitivity in severely resistant type I diabetes mellitus. Journal of Clinical Endocrinology and Metabolism 79 435-440.

Zapf J, Schoenle E, Waldvogel M, Sand I \& Froesch ER 1981 Effect of trypsin treatment of rat adipocytes on biological effects and binding of insulin and insulin-like growth factors. Further evidence for the action of insulin-like growth factors through the insulin receptor. European Journal of Biochemistry 113 605609.

Zapf J, Hauri C, Waldvogel M \& Froesch ER 1986 Acute metabolic effects and half-lives of intravenously administered insulin-like growth factors I and II in normal and hypophysectomized rats. Journal of Clinical Investigation 77 1768-1775.

Received 16 March 2000

Revised manuscript received 28 August 2000

Accepted 7 September 2000 